\title{
Recurrent Pulmonary Hemangioma: A Case Report
}

\section{Janah $\mathbf{H}^{*}$, Bopaka RG, ElKhattabi W, Affif $\mathbf{H}$ and Aichane A}

Respiratory Diseases Department, "20 Aout 1953" Hospital, Casablanca, Morocco

\begin{abstract}
Pulmonary Angioma is an extremely rare benign vascular tumor, affecting, in exceptional cases, some adults. The risk of multiple and postoperative recurrence is rare but should not be ignored in order to establish.

We report a case of recurrent pulmonary hemangioma, revealed by chest pain and recurrent hemoptysis for a 27 year old woman who has a medical history of right lower lobectomy indicated in front of a proximal tissue process right lower lobe.
\end{abstract}

Subsequently, the patient had extra-pulmonary locations based on the radio-clinical setting: aggressive Angioma in the lumbar vertebra of L3 confirmed via biopsy, skull Angioma and left distal femoral Angioma.

\section{Keywords: Hemangioma; Lung; Hemoptysis; Recurrent}

\section{Introduction}

Pulmonary Angioma is an extremely rare benign vascular tumor, affecting primarily youth and, in exceptional cases, some adults. A single case of recurrent pulmonary Hemangioma has been reported and documented up until today [1]. The aim of our study is to report a medical observation of a case of recurrent Pulmonary Angioma. Based on this case, authors emphasize the need to consider this diagnosis when faced with lung tissue processes with recurrent hemoptysis where the prognosis may be at stake.

\section{Case Report}

The case is about a 27 year old woman, housewife. She had a medical history of right lower lobectomy indicated in front of a proximal tissue process right lower lobe. The Histopathological study of the surgical specimen, which followed the immunohistochemistry study, concluded a revised pulmonary hemangioma. The post-operative evolution was good. Subsequently, the patient had extra-pulmonary locations based on the radio-clinical setting: aggressive Angioma in the lumbar vertebra of L3 confirmed via biopsy, skull Angioma and left distal femoral Angioma.

One year after the right lower lobectomy, the patient presented again recurrent hemoptysis of average abundance along with subscapular chest pain and right-lateral sternal, inducing to general condition deterioration.

At her admission to the department, the hemoptysis have become of high flow, and have become complicated with the occurrence of consciousness disorders and hemodynamic instability, which required her stay in the intensive care unit to receive blood transfusion.

At her return to our department, the patient had recurrent hemoptysis of average abundance associated with very persistent chest pain refractory to analgesics. The CT-scan showed a slight increase from an average mediatisnale mass measuring 34.8/54 mm (mass mediatisnale highlighted previously in a CT scan performed at the beginning of the onset of hemoptysis).

Flexible bronchoscopy was deferred to the hemodynamic instability of the patient. Thereafter, the patient was sent off in her hemoptysis blackish membranes, and a histopathological study was requested. We got the results of the histological study, which reconfirmed the diagnosis of pulmonary Angioma. The angiography performed after removal of the membranes showed a reduction in size of the right médiatisnale mass compared to former thoracic scanners, with the presence of a range of frosted glass Fowler and left basal pyramid.
The evolution was marked by the improvement in the general condition of the patient with chest pain loss and depletion of hemoptysis. The patient was referred to the radiotherapy department for possible treatment of brain and spinal angiomas. Orthopedic surgery is scheduled for femoral Angioma. Periodic monitoring is intended to serve. Thoracic surgery was denied because high post-operative risks.

\section{Discussion}

Pulmonary hemangioma is a congenital lesion, benign blood vessel leading to dilated vascular structures. There may appear at birth or during childhood or even more rarely in adulthood.

It can affect any organ with a predilection for the liver and skin [24]. Pulmonary localization is very rare, only a few cases of pulmonary hemangioma have been reported in the literature (Table 1) [5,3]. The majority of cases have been decried in premature or more rarely in small children [5-7]. The clinical manifestations were very different from asymptomatic tables respiratory distress and hemoptysis cataclysmic life-threatening [8]. Fugoand al reported [9] two cases of pulmonary hemangioma in two asymptomatic middle-aged adults. Both discovered radiologically as nodules frosted glass [9]. Eun Young Kim and al also reported two cases of pulmonary hemangiomas shaped solitary nodules [1]. In both cases, the diagnosis of bronchogenic carcinoma was argued before the pathology results confirmed the diagnosis of hemangioma. Histologic confirmation is necessary because of the difficulty of differentiating radiologically a bronchogenic carcinoma [9].

Two cases of recurrence has been reported in the literature $[1,10]$ one of them is a young woman of 22 years, 50 months after resection of pulmonary left nodules, which the anatomopathology study confirmed angiomatosis origin. New pulmonary nodules were detected in a chest radiograph. A CT-scan performed revealed two recurrent nodules, one in the left lower lobe, and the other in the lower right lobe with

*Corresponding author: Hind Janah, Respiratory Diseases Department "20 Aout 1953" Hospital, Casablanca, Morocco, Tel: 0522-48-30-30; E-mail: hindjanah79@gmail.com

Received December 22, 2013; Accepted January 10, 2014; Published January 15,2014

Citation: Janah H, Bopaka RG, ElKhattabi W, Affif H, Aichane A (2014) Recurrent Pulmonary Hemangioma: A Case Report. J Pulm Respir Med 4: 165. doi:10.4172/2161-105X. 1000165

Copyright: $\odot 2014$ Janah H, et al. This is an open-access article distributed under the terms of the Creative Commons Attribution License, which permits unrestricted use, distribution, and reproduction in any medium, provided the original author and source are credited. 
Citation: Janah H, Bopaka RG, ElKhattabi W, Affif H, Aichane A (2014) Recurrent Pulmonary Hemangioma: A Case Report. J Pulm Respir Med 4: 165. doi:10.4172/2161-105X. 1000165

Page 2 of 2

\begin{tabular}{|c|c|c|c|c|c|c|c|}
\hline Reference & Case (n) & Age at diagnosis & Sex & Clinical symptoms & $\begin{array}{l}\text { Radiologic findings } \\
\text { (location) }\end{array}$ & Follow-up & Pathology \\
\hline $\begin{array}{l}\text { Bowyer and Sheppard } \\
\text { [1] }\end{array}$ & 1 & Neonate & $\mathrm{F}$ & Respiratory distress & $\begin{array}{c}\text { A } 6 \mathrm{~cm} \text { sized air filled } \\
\text { cyst (RLL) }\end{array}$ & $\begin{array}{l}\text { No recurrence after lobectomy, } \\
\text { (follow up period is NA) }\end{array}$ & \\
\hline Galliani et al. [5] & 1 & 10 wks & M & Rhinorrhea, cough & A $7 \mathrm{~cm}$ sized mass (RLL) & $\begin{array}{l}\text { No recurrence after lobectomy, } \\
\text { (follow up period: } 12 \text { months) }\end{array}$ & $\begin{array}{c}\text { Cavernous } \\
\text { hemangioma }\end{array}$ \\
\hline \multirow[b]{2}{*}{ Abrahams et al. [6] } & 2 & 8 wks & M & Respiratory distress & A cystic mass (RLL) & $\begin{array}{l}\text { No recurrence after wedge } \\
\text { resection (follow up period is NA) }\end{array}$ & $\begin{array}{l}\text { Localized capillary } \\
\text { hemangioma }\end{array}$ \\
\hline & & $9 \mathrm{yrs}$ & $\mathrm{F}$ & Cyanosis clubbing & $\begin{array}{l}\text { Multiple nodules } \\
\text { simulating ILD } \\
\text { (predominantly right } \\
\text { lung) }\end{array}$ & Died of massive hemoptysis & $\begin{array}{l}\text { Multifocal capillary } \\
\text { hemangioma }\end{array}$ \\
\hline \multirow{2}{*}{ Fugo et al. [9] } & 2 & 56yrs & M & No specific symptom & $\begin{array}{c}\text { A small semisolid nodule } \\
(\mathrm{LLL})\end{array}$ & NA after segmentectomy & $\begin{array}{l}\text { Localized capillary } \\
\text { hemangioma }\end{array}$ \\
\hline & & $48 \mathrm{yrs}$ & $\mathrm{F}$ & No specific symptom & $\begin{array}{c}\text { A small semisolid nodule } \\
\text { (RML) }\end{array}$ & NA after wedge resection & $\begin{array}{l}\text { Localized capillary } \\
\text { hemangioma }\end{array}$ \\
\hline Capizzani et al. [7] & 1 & Neonate & M & Respiratory distress & Huge mass (right lung) & $\begin{array}{l}\text { No recurrence after resection } \\
\text { (followup period: } 6 \text { months) }\end{array}$ & $\begin{array}{l}\text { Both of capillary and } \\
\text { cavernous component }\end{array}$ \\
\hline
\end{tabular}

Table 1: Summary of pulmonary hemangiomas reported in literature.

maximum diameters of 30 and $12 \mathrm{~mm}$ respectively. A left lower lobectomy and wedge resection of the right lower lobe were performed. The comparison of the results of the histological study with the nodules resected 50 months before, confirmed the recurrence of pulmonary hemangioma.

\section{Conclusion}

Pulmonary hemangioma is a rare vascular tumor that occurs mainly in young patients. The risk of multiple and postoperative recurrence is rare but should not be ignored in order to establish an appropriate management. The prognosis of this tumor can be bad because of the risk of recurrent hemoptysis.

\section{References}

1. Kim EY, Kim TS, Han J, Kim H, Choi YS (2012) Recurrent pulmonary capillary hemangioma: dynamic contrast-enhanced $\mathrm{CT}$ and histopathologic findings. Korean J Radiol 13: 350-354

2. Abrahams NA, Colby TV, Pearl RH, Chipps BE, Juris AL, et al. (2002) Pulmonary hemangiomas of infancy and childhood: report of two cases and review of the literature. Pediatr Dev Pathol 5: 283-292.
3. Capizzani TR, Patel H, Hines MH, Mott RT, Petty JK (2008) A unique case of a giant congenital pulmonary hemangioma in a newborn. J Pediatr Surg 43: 574-578.

4. Dinehart SM, Kincannon J, Geronemus R (2001) Hemangiomas: evaluation and treatment. Dermatol Surg 27: 475-485.

5. Bowyer JJ, Sheppard M (1990) Capillary haemangioma presenting as a lung pseudocyst. Arch Dis Child 65: 1162-1164.

6. Galliani CA, Beatty JF, Grosfeld JL (1992) Cavernous hemangioma of the lung in an infant. Pediatr Pathol 12: 105-111.

7. Taniguchi D, Taniguchi H, Sano I, Tamura K, Shindou H, et al. (2010) [Solitary capillary hemangioma in the lung: report of a case]. Kyobu Geka 63: 423-425.

8. Cho NJ, Baek AR, Kim J, Park JS, Jang AS, et al. (2013) A case of capillary hemangioma of lingular segmental bronchus in adult. Tuberc Respir Dis (Seoul) 75: 36-39.

9. Fugo K, Matsuno Y, Okamoto K, Kusumoto M, Maeshima A, et al. (2006) Solitary capillary hemangioma of the lung: report of 2 resected cases detected by high-resolution CT. Am J Surg Pathol 30: 750-753.

10. KVERENCHKHILADZE VK (1962) [A case of surgical treatment of recurrent angioma of the lung]. Grudn Khir 4: 93-94. 